\title{
Conceptualization of Ethnic Identity Formation in Sri Lanka: An Explanation to the Evolution of Ethnic Conflict
}

\author{
Jayalathge Thumira Sampath Gunasena \\ University of Auckland, New Zealand
}

\begin{abstract}
Primordialism, constructivism, instrumentalism and institutionalism attempt at explaining what constitutes ethnicity. This paper explains how different events had been crucial in ethnic identity formation in Sri Lanka, based on contrasting meanings given to these events by various actors in constructing the master narrative of ethnic conflict. Sri Lankan chroniclers and postindependence ethnic protagonists added nationalist sentiments into the ethnic consciousness of the people and even today these primordial sentiments were visible in the Sri Lanka polity. Instrumentalism explained that post-colonial Sinhalese majority governments instrumentally adopted discriminating polices towards the minority Tamils in restoring Sinhalese's majority rights undermined by the British. Consequently, institutionalisation of such polices created an ethnic outbidding and a massive disparity between the two ethnicities. Then it evolved as a struggle between the two conflictual parties, the Liberation Tigers Tamil Eelam (L.T.T.E) demanding self- determination and secessionism and the government and its societal supporters seeking a solution within a unitary state framework. Negotiated peace became an unattainable goal as the two state building projects lacked any shared goal. After 2009, in the absence of the L.T.T.E positive peace yet remains an unresolved puzzle. The radicalization of Bikku politics, transformation of Tamil identity politics, and international involvement in the domestic justice discourse had added new dimensions to the master narrative of the conflict. This paper concludes that multiple actors engaged in various events giving different meaning to them have constructed the master narration of conflict. Therefore evolution of conflict is socially constructed and able to explain through constructivist approach.
\end{abstract}

Key words: primordialism; constructivism; institutionalization; ethnic outbidding; identity formation 